Studia Oecumenica 17 (2017)

DOI: $10.25167 / \mathrm{SOe} / 17 / 2017 / 195-208$

JAROSŁAW MOSKAŁYK

Wydział Teologiczny UAM

\title{
Wplyw idei protestanckiej \\ na myśl prawosławną w wyniku unii brzeskiej w 1596 roku
}

\author{
Influence of the Protestant Idea \\ on the Orthodox Thought in the Result of the Union of Brest in 1596
}

\begin{abstract}
The event of the Brest union from 1596 apart from a unification historic act caused an also meaning exchange of ideas religious among the Catholic, Orthodox and Protestant denomination. As a result of it gaining by individual denominations more expressive views happened in many theological issues. Polemical character of the discourse resulted in also an appearance of different influences and doctrinal relations. Against this background they were seen more permeation of the Protestant intuition to the Orthodox doctrine and influence of the Latin position on the position of eastern Catholics of the Kiev tradition. However the multilateral doctrinal confrontation contributed with time to the considerable search of teaching in the Orthodox Church and change attitudinal of eastern Catholics towards the Latin influence.
\end{abstract}

Keywords: protestant idea, orthodox thought, Brest union, sovereignty, mystery, future.

\section{Streszczenie}

Wydarzenie unii brzeskiej z 1596 r. oprócz historycznego aktu zjednoczeniowego spowodowało również znaczącą wymianę myśli religijnej między wyznaniem katolickim, prawosławnym i protestanckim. W wyniku tego doszło do wypracowania przez poszczególne wyznania bardziej wyrazistych poglądów w wielu kwestiach ściśle teologicznych. Główną platformą dyskusji stała się wówczas idea unii, wokół której podejmowano złożone zagadnienia dogmatyczne, eklezjologiczne, liturgiczne i inne. Na tym tle uwidoczniły się W sposób szczególny przenikanie intuicji protestanckiej do doktryny prawosławnej oraz wpływ stanowiska łacińskiego na pozycję wschodnich katolików tradycji kijowskiej. Jednak wielostronna konfrontacja doktrynalna przyczyniła się z czasem do znacznej rewizji nauczania w Kościele prawosławnym i zmiany orientacji wschodnich katolików względem oddziaływania łacińskiego.

Słowa kluczowe: idea protestancka, myśl prawosławna, unia brzeska, zwierzchnictwo, misterium, przyszłość. 
Projekt zjednoczenia Kościoła prawosławnego tradycji kijowskiej ze Stolicą Apostolską, mimo poparcia większości hierarchów i bractw cerkiewnych w latach 80. XVI w., ostatecznie napotkał na duży sprzeciw obozu związanego z księciem Konstantynem Ostrogskim (1526-1608). Ten opór wcale nie zmalał, lecz jeszcze bardziej się nasilił po zawarciu unii w 1596 r. oraz przybrał postać bardziej metodycznego zwalczania całej idei. Jednak zanim doszło do podpisania historycznego aktu „odnowienia jedności” z Rzymem, jego przeciwnicy na czele z Ostrogskim postanowili zdecydowanie przeciwstawić się pomysłowi przy wykorzystaniu ideowej inspiracji protestanckiej. Było to podyktowane przede wszystkim względami praktycznymi, czyli z jednej strony ogólnie niską wiarygodnością własnego Kościoła oraz z drugiej - sprzyjającymi okolicznościami narastającej opozycji protestantyzmu wobec Kościoła łacińskiego. W tym celu doszło nawet do zawiązania pewnej koalicji między prawosławnymi i protestantami celem zwalczania unii i katolickiej doktryny kościelnej. Jako potwierdzenie tego faktu można wskazać chociażby obecność delegacji księcia Ostrogskiego na synodzie różnowierczym w Toruniu w $1595 \mathrm{r}^{1}$

Dla niektórych środowisk prawosławnych otwarcie się na protestantyzm w warunkach jednoznacznych tendencji unijnych w swoim Kościele oraz wzmagającego się w nim kryzysu wydawało się być czymś naturalnym i niezbędnym. Tutaj w zbliżeniu z doktrynalnym nurtem protestanckim dostrzegano szansę faktycznego oparcia się niebezpieczeństwu czynnika unijnego na Wschodzie i zarazem perspektywę prawdziwego odrodzenia duchowych wartości prawosławnych. Natomiast w znacznie mniejszym stopniu brano pod uwagę zakres wpływu i zależności wobec reformatorskich wizji teologicznych, czy tym bardziej ich konsekwencji dla zachowania tradycyjnych przymiotów religii prawosławnej i organizacyjno-sakramentalnej ciągłości jednej wspólnoty, o czym zaświadczy późniejsza zmiana nastawienia prawosławnych Kościoła kijowskiego i greckiego w stosunku do protestantyzmu. Zagadnienie to wraz z niektórymi aspektami kontrowersji teologicznych stanie się podstawą poniższych rozważań i przedmiotem końcowych wniosków.

\section{W nurcie oddziaływania}

Potrzeba chwili, którą uzasadniało potencjalne zawarcie unii, niejako zmuszała prawosławnych tradycji kijowskiej pod koniec XVI w. do ożywienia kontaktów z protestantami. Chodziło tu głównie o zdobycie konkretnego wsparcia

${ }^{1}$ Por. T. Glemma, Stosunki kościelne w Toruniu w stuleciu XVI i XVII na tle dziejów kościelnych Prus Królewskich, Toruń 1934, 88-89. 
merytorycznego w sprzeciwie dążeniom unijnym w swoim Kościele. Przeciwnicy unii zatem uznali, że nauczanie Lutra i Kalwina może posłużyć jako właściwy punkt odniesienia i zarazem przeciwwagę dla nieposkromionych intencji pewnych grup społeczno-religijnych. Ponieważ teorie protestanckie zdobywały wówczas coraz potężniejszą liczbę zwolenników, z tym większą łatwością mogły się przedostawać do środowisk prawosławnych na Wschodzie Europy za pośrednictwem licznych uczniów Reformacji. W ten sposób współpraca prawosławno-protestancka uzyskała oprócz podłoża religijnego również wymiar kulturowy między obiema konfesjami. Innym powodem nieskrępowanego przenikania ich doktryny do prawosławia kijowskiego na przełomie XVI i XXII w. było moralne oparcie w postawie ośrodka patriarszego w Konstantynopolu. Ten bowiem w XVI w. niejednokrotnie wykazywał duże zrozumienie i przychylność dla ułożenia dobrych relacji z protestantami². Pojawiały się nawet pewne przesłanki do nawiązania jedności między wyznaniami reformowanymi a Kościołem w Bizancjum. Jednak różnice pozostawały wciąż na tyle poważne, że uniemożliwiły jej realizację.

Tym niemniej okazywana wyrozumiałość dla działań reformatorów ze strony patriarchów ekumenicznych oraz napięta sytuacja w Kościele kijowskim jedynie zachęcały propagatorów idei protestanckiej do polemiki z katolikami. Do szczególnie wyróżniających się pod tym względem postaci należy zaliczyć: Sibranda Lubberta (1555-1625) i Rudolfa Gualthera (1519-1586), którzy z dużą pasją atakowali głównie katolicką doktrynę o prymacie papieża i przewodnictwie biskupa Rzymu w Kościele. Ten rodzaj retoryki podjęty przez reformatorów niezwykle odpowiadał przeciwnikom unii w Kościele kijowskim i stał się ich właściwym zapleczem argumentacyjnym w konfrontacji z drugą stroną ${ }^{3}$. Jednak największy wpływ na myśl prawosławną wywarł Marek Antoni de Dominis (1566-1624). Jako wychowanek jezuitów i następnie arcybiskup w Dalmacji (Wenecja) w pewnym momencie postanowił przeciwstawić się papieżowi i zająć stanowisko bliskie doktrynie protestanckiej. Jego kontrowersyjne poglądy na temat katolickiej nauki o Kościele ${ }^{4}$, panujących w nim zwyczajach i obietnicy nadania prymatu św. Piotrowi (Mt 16,17-19) ${ }^{5}$, zdobyły ogromny rozgłos wśród prawosławnych i przez pewien okres były tu traktowane jako wzór prawdziwej wykładni teologicznej.

${ }^{2}$ Jako przykład można podać prowadzenie korespondencji między patriarchą Jeremiaszem II a Melanchtonem, którą strona katolicka wykorzystała później w polemice z prawosławnymi. Por. S. Runciman, Wielki Kościót w niewoli, Warszawa 1973, 264-282.

${ }^{3}$ Por. P. Skwarczyński, Szkice z dziejów reformacji w Europie Środkowo-Wschodniej, Londyn 1967, 72-75.

${ }^{4}$ Zob. M.A. DE Dominis, Papatus Romanus seu de origine progressu atque extinctione eius, w: Dictionnaire de Théologie Catholique, t. IV, London 1617, 1668-1675.

${ }_{5}^{5}$ M.A. DE Dominis, De republica eccelesiastica, Heidelberg 1618. 
Na postawę prawosławnych w polemice z katolikami znaczący oddźwięk wywarła również twórczość uczonego Greka Cyryla Lukarisa (1572-1638), późniejszego patriarchy Konstantynopola. Dzięki zdobytemu wykształceniu w Rzymie oraz rozległym kontaktom ze światem zachodnim Lukaris dał się dość łatwo uwieść inspiracji ruchu reformatorskiego. Pozostając pod wpływem przede wszystkim Marka Antonio de Dominisa oraz innych entuzjastów idei kalwinistycznych, postanowił opracować Wyznanie wiary prawosławnej (Confessio Fidei Ortodoxae). To Wyznanie z 1629 r. wprowadziło wiele zamieszania wśród prawosławnych oraz katolików. Stąd synod w Konstantynopolu zdecydował w 1638 r. i jeszcze kilka razy później o potępieniu dzieła i uznaniu Cyryla jako heretyka. Podobne stanowisko zajął Kościół prawosławny tradycji kijowskiej na soborze w Kijowie 8-19 września 1640 r. ${ }^{7}$ Przy czym wcześniej zachowywano tu dużą powściągliwość, a nawet starano się nie nadawać Wyznaniu szczególnego rozgłosu.

Było to spowodowane żywotnym interesem, który polegał na bezpośrednim i szerokim odwoływaniu się do literatury i treści teologicznych pochodzenia protestanckiego. W zasięgu ich oddziaływania pozostawali najbardziej zagorzali polemiści prawosławni, jak Zachariasz Kopysteński († 1627), Stefan Tustanowski-Zizania [Kąkol] († 1600), Wasyl Surazki (ok. † 1608), Melecjusz Smotrycki $(\dagger 1633)$ i wielu innych. Na bazie zapożyczonych teorii formułowano główne zarzuty pod adresem unii i błędów wynikających z doktryny katolickiej. Należy zauważyć, iż prawosławni dopiero $\mathrm{w}$ wyniku powstania kontrowersji w łonie chrześcijaństwa łacińskiego i jego podziału w XVI w. oraz kryzysu unijnego w Kościele kijowskim na przełomie XVI i XVII w. postanowili aktywnie włączyć się w zaistniały spór, wchodząc niejako drogą naturalną w bliskie relacje z protestantami i w równie oczywisty sposób czerpiąc z ich spuścizny dogmatycznej. Przedtem raczej nie odczuwali większej potrzeby rozwijania i precyzowania nauki o podstawowych prawdach wiary. Gdyż ta, w ich pojęciu, otrzymała właściwy i pełny kształt na soborach powszechnych. Do najbardziej wyrazistych oponentów błędnego nauczania „dyzunickiego” należeli głównie katoliccy hierarchowie i duchowni Kościoła kijowskiego, a wśród nich: metropolita Hipacy Pociej (1541-1613), metropolita Józef Rutski (ok. 1547-1637), metropolita Antoni Sielawa (ok. 1583-1655), abp Jozafat Kuncewicz (1580-1623), abp Leon Kreuza (1569-1639), abp Melecjusz Smotrycki (1577-1633), bp Eliasz Morochowski (ok. 1576-1631), bp Jakub Susza (ok. 1610-1685), ks. Jan Dubowicz $(† 1646)$, ks. Kasjan Sakowicz (1578-1647), duchowny Grek Piotr Arkudiusz (1562-1633) i inni.

${ }^{6}$ M. JUGIE (red.), Theologia dogmatica christianorum orientalium, t. I, Paris 1926, 504-514, 656-666.

7 Zob. М. Грушевський, Історія України-Руси, t. VII, cz. 2, Київ 1995, 89-92. 


\section{Zasada zwierzchnictwa w Kościele}

Wyzwanie konfrontacji pounijnej ujawniło w pierwszym rzędzie rzeczywisty stosunek stron do Kościoła jako widzialnej struktury i podlegającej przewodnictwu biskupa Rzymu. Prawosławni od początku podkreślali, że o prawdziwości i zbawczym charakterze Kościoła decydują obecność w nim Chrystusa i moc działania Ducha Świętego, nie zaś skuteczne sprawowanie funkcji zwierzchnika widzialnego w osobie papieża. W ten sposób sprzeciwiono się idei wspólnotowej więzi jurysdykcyjnej z biskupem Rzymu jako głową widzialną. Dla nich, jak i protestantów, pojęcie „Skała” (Mt 16,18) odnosi się wyłącznie do Chrystusa. Nazywanie zatem Piotra „Skałą” wskazywałoby na wyjątkowość jego wiary i rodzaj przywileju w stosunku do innych apostołów, a w konsekwencji zachwianie autorytetu władzy kolegium apostolskiego ${ }^{8}$. Z kolei zwolennicy unii dostrzegali w pierwszoplanowej roli papieża nieodzowne kryterium jedności Kościoła. Wyjaśniano przy tym, iż pierwszeństwo papieża w Kościele doczesnym nie uprawnia go do dysponowania prerogatywami przynależnymi Chrystusowi. Ono jest niezbędne dla zachowania porządku, dyscypliny i widzialnej jedności całej wspólnoty wierzących. Tego pragnął Chrystus, aby Kościół stanowił jedność oraz posiadał jedną głowę i najwyższego pasterza zdolnego jednoczyć wszystkich w imię swego Pana?.

Prezentowana wizja prymatu wschodnich katolików była zbliżona do łacińskiej, co wzbudzało nad wyraz negatywną reakcję strony prawosławnej. Ta bowiem odrzucała nie tylko przywilej władzy papieża, ale także związany z nią przymiot jednoczenia wspólnoty kościelnej. Uważano, iż jest to dalekie nadużycie i próba bezprawnego podporządkowania sobie wspólnot nie będących w łączności z Rzymem. Poglądy te ściśle korespondowały z ówczesną protestancką doktryną o zewnętrznej i instytucjonalnej podstawie Kościoła. Protestanci stawiali mocno akcent na wewnętrznej jedności Kościoła, która jest najważniejsza i zabezpiecza jego trwanie na ziemi. Ona też pozostaje niezastąpiona w dążeniu doczesnej wspólnoty wierzących do pełnego pojednania w Bogu. Nadto uczono, że zewnętrzna forma Kościoła nie może spełniać nadrzędnej roli duchowego umocnienia i pojednania osób czy wspólnot między sobą. W tej koncepcji chodziło o podważenie katolickiej idei o hierarchicznej strukturze Kościoła. Natomiast jego instytucjonalny wymiar był tu

${ }^{8}$ A. IszczaK, De Zacharia Kopystynskyj eiusque „Palonodia” opera polemico contra primatum R. Pontificis et unionem confecto, Boh 9 (1931) 1-2, 64-66; por. F. Melanchton, Die potestate papae, w: C.G. BretschneIDER (wyd.), Corpus Reformatorum, t. III, Halis Saxonum 1836, 271-284.

${ }^{9}$ Ep. Susza Joanni Vyhovskyj duci Cosacorum. Fuse exponit doctrinam de vera Ecclesia, de primatu Pontificis Romani, de causis schismatis Graecorum et de promovenda unione cum Ecclesia Catholica omnium Ruthenorum, w: A. SEPTYCKYj (wyd.), Monumenta Ucrainae Historica, t. III, Romae 1966, 48-49. 
postrzegany jako rodzaj przeciwwagi do wymiaru nadprzyrodzonego oraz mający charakter bardziej destruktywny niż scalający ${ }^{10}$.

Prawosławnym ta interpretacja w dużym stopniu odpowiadała, gdyż mogli przede wszystkim wykazywać słuszność swego sprzeciwu wobec katolickiego prymatu jurysdykcyjnego w Kościele, jednocześnie z zachowaniem własnej intuicji hierarchicznego ustroju Kościoła czynić wyraźne aluzje w stronę łacińskiej formuły jego realizacji. Prawosławni stali na stanowisku, że w tym świecie Kościołowi Chrystusowemu bardziej przystoi ubóstwo. Jego droga musi biec wśród prześladowań, gdzie sposób zarządzania i jakość organizacji powinny pozostać $\mathrm{w}$ cieniu. Bo w istocie o jego prawdziwości stanowi wewnętrzne zespolenie z Bogiem, a nie samospełnienie w widzialnej jedności. Na co wschodni katolicy zwykle odpowiadali, że takie podejście dowodzi uproszczonego ujęcia wydarzenia Kościoła w wymiarze całościowym i niepodzielnym. Tym samym istnieją podstawy, aby podejrzewać prawosławnych wraz z protestantami o pogardę względem samego Chrystusa. Dlatego nawet najszczersze zapewnienia o dochowaniu cerkiewnej wierności oraz trwaniu w mocy sakramentalnej nie mogą usprawiedliwić powziętej postawy podeptania najwyższego nakazu ${ }^{11}$.

Odrzucając prawosławną naukę o prymacie papieża jako głęboko przenikniętą ideą eklezjologii protestanckiej, katolicy Kościoła kijowskiego starali się najczęściej w sposób rzeczowy uzasadnić wypaczenia i błędy doktrynalne po przeciwnej stronie. „Prawdziwy Kościół jest tam, gdzie jawnie wiarę chrześcijańską wyznawają (...), gdzie nie masz herezji ani jawnej niezbożności, ani niedowiarstwa - w nauczanie najwyższego Pasterza - gdzie prawdziwa a nienaruszona wiara"12. Według nich, Jezus powierzył funkcję pasterską swojej owczarni, widzialnie określonej i zorganizowanej, w której On nadal sprawuje właściwą władzę zbawczą, do której dostępu udzielił także Piotrowi ${ }^{13}$. Zdarzało się ponadto, że w polemice używano dosadnego słownictwa i ostrych porównań, a przy tym mniej merytorycznej argumentacji. „Nie pomoże pośrednik Jezus, boście namiestnikiem Jezusa wzgardzili. Święte nie pomogą sakramenta, boście okrutną ręką szafarzowi onych Piotrowi klucze królestwa wydarli"14. Zapewne tak musiała wyglądać wymiana zdań i stanowisk między katolikami, prawosławnymi

${ }^{10}$ Por. M. Rechowicz, Teologia pozytywno-kontrowersyjna, w: TENŻE (red.), Dzieje teologii katolickiej w Polsce, t. II, cz. 1, Lublin 1975, 52-75.

${ }^{11}$ H. PocıeJ, Kazania y homilie Męża Bożego - nieśmiertelnej sławy, y pamięci H. Pocieja. Od niedzieli przedzapustnej do niedzieli i poniedziałku Zesłania Ducha Świętego, Supraśl 1714, 398.

12 TENŻE, Harmonia albo konkordancja Cerkwi orientalnej z Kościołem rzymskim..., Русская Историческа Библиотека, издаваема Археографіческой комиссиею, t. VII, Санкт-Петербург 1878, 190-191.

${ }^{13}$ L. KReUZA, Obrona jedności cerkiewney abo dowody ktoremi się pokazuje, iż Grecka Cerkiew z Lacińska ma być zjednoczona, Русская Историческа Библиотека, издаваема Археографіческой комиссиею, t. 4, Санкт-Петербург 1878, 166.

${ }^{14}$ H. Pocies, Kazania y homilie, 274. 
i protestantami w szczytowym momencie konfesyjnego napięcia wywołanego unią brzeską. Ta sytuacja miała przełożenie na całościowy poziom debaty teologicznej, który często pozostawał wiele do życzenia z powodu swego charakteru moralizatorskiego.

\section{Różnice w celebracji jednego misterium}

Teologowie katoliccy nurtu kijowskiego często podkreślali, że rozwój tradycji Kościoła dopuszcza różnorodność formuł, które w swej istocie nie powodują rozbieżności w wymiarze dogmatycznej treści wiary. Tutaj skupiano się przede wszystkim na celebracji misterium Eucharystii, które zarówno w wschodniej, jak i zachodniej tradycji wyraża wspólną wiarę w prawdziwą przemianę chleba w Ciało, a wina w Krew Chrystusa ${ }^{15}$. Dlatego stosowanie m.in. różnych anafor eucharystycznych w żadnym razie nie narusza jednego i tego samego misterium zbawczego. Kościół prawdziwie wypełnia swoje posłannictwo wówczas, gdy nieprzerwanie sprawuje Eucharystię. Członkami Kościoła są zaś ci, którzy biorą w niej udział, ponieważ w Eucharystii Chrystus, zgodnie z własną obietnicą, ,jest z nami aż do końca świata"16.

Dla strony katolickiej stało się rzeczą daleko niezrozumiałą, iż prawosławni w sporze pounijnym zasadniczą uwagę skierowali na rodzaj materii eucharystycznej. Zwłaszcza że ta kwestia nie dotyczyła żadnej ze stron wschodnich, gdyż obie zachowywały pod tym względem całkowite podobieństwo, lecz mogła się odnosić wyłącznie do łacinników. To potwierdzało jedynie ich uległość tendencjom protestanckim. Według wschodnich katolików poddanie w wątpliwość ważności ofiary eucharystycznej sprawowanej na chlebie przaśnym czy Komunii św. pod jedną postacią w tradycji łacińskiej stanowiło wyraz głębszej asymilacji przez prawosławnych obcych (protestanckich) zwyczajów. Tymczasem prawdziwym dowodem, że chleb przaśny nie jest zwykłym wymysłem ludzkim i nie może być przyczyną niezgody między Kościołami, pozostaje wciąż pamiątka Ostatniej Wieczerzy. „Kościół rzymski w sakramencie najświętszym używa chleba przaśnego na znak tego, iż ciało Pana Krystusowe jest czyste i bez wszelkiej zmazy i grzechu. A kwas dlatego nie używa, iż w Piśmie Świętym kwas grzech znaczy"17.

${ }_{15}$ M. SMOtrycki, Consideratiae abo uważania sześciu różnic między Cerkwia Wschodnia i Zachodnia..., Lwów 1628, przedr. Collected Works of Meletij Smotryc'kyj, t. I, Cambridge, MA 1987, 166.

${ }^{16}$ H. PocIEJ, List dogmatyczny do patriarchy aleksandryjskiego Melecjusza, w: TENŻE, Kazania y homilie, Supraśl 1714, 52-53.

${ }_{17}$ M. SмотRYCKI, Apologia peregrynacji do krajów wschodnich..., Lwów 1628, przedr. Collected Works of Meletij Smotryc'kyj, t. I, 115-116. 
Choć we wschodniej liturgii używa się chleba kwaszonego jako symbolu Chrystusa, który przyjął człowieczeństwo i stał się prawdziwą jednością złożoną z ciała i duszy, to jednak nie przekreśla autentycznego wymiaru znaku chleba przaśnego. „Rzymski Kościół, chociaż sakrament w przaśnym chlebie poświęca, wedle ustawy Pana Chrystusa, i nie gani w tym naszej Cerkwi, wiedząc, że jednakowo, jako przaśny, tak kwaśny chleb jest chlebem" ${ }^{18}$. Podobnie rzecz dotyczy Komunii pod jedną postacią, gdyż Kościół zawsze wierzył w prawdziwą i pełną obecność Chrystusa pod każdą postacią. Dlatego przyjmując Komunię św. pod jedną czy pod dwoma postaciami, przyjmuje się niewątpliwie całego i niepodzielonego Chrystusa do serca swego. On jest przecież jednakowo obecny w całym chlebie eucharystycznym i w najmniejszych okruchach ${ }^{19}$.

Aby móc w sposób pełny uczestniczyć w liturgii eucharystycznej i przyjmować z godnością najświętsze dary Ciała i Krwi, trzeba najpierw z wiarą przyjąć wielkość Ofiary ustanowionej przez samego Chrystusa. To zaś sprawia określoną trudność protestantom, którzy uznają tylko symboliczną obecność Chrystusa pod postacią chleba i wina oraz zachowują swoistą obojętność wobec pojęcia ofiary eucharystycznej. I tak, zdaniem katolików tradycji kijowskiej, niebezpiecznemu wpływowi ulegli prawosławni, naśladując również ów błędny kierunek interpretacji, o czym dowodzi przynajmniej częściowa utrata należytej wrażliwości względem Eucharystii jako ofiary błagalnej za żywych i umarłych ${ }^{20}$. Uważano, że dla takiej postawy nie może być usprawiedliwienia, ponieważ cały Kościół wschodni, w tym grecki i ruski, celebruje liturgię eucharystyczną jako ofiarę za żywych i umarłych ${ }^{21}$. W tym wyraża się głęboki akt więzi, który potwierdza żywe relacje między światem nadprzyrodzonym i doczesnym ${ }^{22}$.

Jakkolwiek nie podejmowano tu szczegółowej wykładni teologicznej błędów i wypaczeń, ani stopnia zależności prawosławnych, to już same zbliżenie wobec protestantyzmu surowo potępiono. Podobnie zresztą postępowała strona prawosławna, która mocno ganiła i negowała, w jej rozumieniu, dziwne zwyczaje związane z doktryną i praktyką liturgiczną Kościoła łacińskiego (np. udzielanie sakramentu chrztu przez polanie wodą, a nie zanurzenie w wodzie chrzcielnej), a zarazem choćby częściowo przejęte przez katolików Kościoła kijowskiego. „Prawosławny narodzie Rusi, wiedz dobrze, że przebywasz w prawdziwym Kościele (...). Dlatego zostań w nim [wytrwale] niezachwianie i niewzruszenie, nie

\footnotetext{
${ }^{18}$ H. Pociej, Harmonia, 207.

19 Por. M. Smotrycki, Consideratiae, 169.

${ }^{20}$ H. Pociej, Harmonia, 200.

${ }^{21}$ M. Sмотrycki, Consideratiae, 174-177.

22 Por. P. Evdokimov, Prawosławie, Warszawa 1986, 316-319.
} 
daj się zachwiać ani wiatrowi [pochlebstw] obłudy, ani burzy prześladowań, ani sławnej dyskusji filozoficznych sylogizmów"23.

\section{Inne widzenie przyszłości}

W okresie średniowiecza jedną z największych rozbieżności między Wschodem a Zachodem była kwestia czyśćca. Główny punkt sporu dotyczył jednak interpretacji sprawiedliwości Bożej w świecie przyszłym. Według poglądów łacińskich sprawiedliwość Boga wymaga zadośćuczynienia za każdy grzeszny czyn. Z kolei strona wschodnia wyjaśniała problem grzechu nie tyle w kategoriach popełnionych czynów, ile bardziej moralnej i duchowej choroby, którą wyleczyć miałoby uzdrowienie i miłość Boga ${ }^{24}$. W XVII w. zagadnienie czyśćca wskutek otwartej polemiki międzykonfesyjnej musiało również zaintrygować prawosławnych i katolików tradycji kijowskiej. Tym razem akcent został bardziej przesunięty na sposób interpretacji sądu Bożego względem istoty ludzkiej. Katolicy, pozostając wierni idei łacińskiej, głosili, że każdy człowiek w momencie śmierci, czyli oddzielenia duszy od ciała, dostąpi sądu indywidualnego (jednostkowego), podczas którego jedne dusze pójdą do miejsca światła i spokoju, a inne do miejsca ciemności i niepokoju ${ }^{25}$.

Dlatego należy przypuścić, iż sprawiedliwi i święci będą w niebie, przestępcy i heretycy zostaną skazani na potępienie, ale musi być także miejsce trzecie, na którym dusze ludzi wypłacać muszą ognia oczyszczenia, czyli trafić do czyśćca $^{26}$. Przekonywano, że istotnie tak będzie w oparciu o Pismo Święte (por. Iz 4,4-5; 1 Kor 3,13-14). Mamy również niezliczone przykłady Ojców Kościoła zarówno wschodniego, jak i zachodniego, jak: Bazyli Wielki, Grzegorz z Nazjanzu, Jan Chryzostom oraz Cyprian, Augustyn, Ambroży, Hilary i inni ${ }^{27}$. Wreszcie odwoływano się do argumentów natury czysto racjonalnej: ,jeśliby założyć, że czyściec nie istnieje, w takim razie trzeba przyjąć, że również niebo nie istnieje (jest zburzone), ale i piekło zatraciło swój sens. To co wówczas będzie się działo z przewrotnymi, heretykami, dla których to, jedno jedyne tylko pozostaje miejsce w piekle?"28.

23 П. МогилА, EYХОЛОГІGN албо Молитословъ, или Требникъ, cz. 2, Київ 1647, 28.

${ }^{24}$ Por. J. Meyendorff, Teologia bizantyjska. Historia i doktryna, Warszawa 1984, 281-283.

${ }_{25}$ M. Sмотrycki, Apologia, 25-26.

${ }^{26}$ Tamże, 29-36. Por. H. Pocies, List dogmatyczny do patriarchy aleksandryjskiego Melecjusza, 101.

${ }_{27}$ M. Smotrycki, Apologia, 33-40.

${ }^{28}$ H. PocIEJ, List dogmatyczny do patriarchy aleksandryjskiego Melecjusza, 103. 
W sporze z prawosławnymi chodziło o podważenie ich tezy o braku pośredniego stanu pośmiertnego (czyśćca) jako niedorzecznego i fałszywego wraz z tym teorii, że wszystkie dusze zmarłych są w „stanie snu” i ich los rozstrzygnie się dopiero na sądzie ostatecznym. W tym przypadku katolicy wskazywali nawet na Lutra, który początkowo nie sprzeciwiał się istnieniu czyśćca oraz dopuszczał jego realność bardziej niż niektórzy prawosławni ${ }^{29}$. Odrzucano również prawosławną naukę o braku jakiejkolwiek kary fizycznej i wszelkiej ekspiacji za grzechy po śmierci (P. Mohyła), przyjmując tylko działanie miłosierdzia Bożego i niesienie pewnej pomocy zmarłym przez modlitwy, jałmużnę, dobre uczynki itd. Jednocześnie oskarżano prawosławnych o pewną sprzeczność pojawiającą się między ich teorią i praktyką liturgiczną w związku ze zwyczajem w Kościele prawosławnym wstawiennictwa modlitewnego za zmarłych, które jest wyrazem wiary w prawdziwe relacje świata zmarłych i żywych. W tym jednak upatrywano oddziaływanie protestantyzmu, który poszedł jeszcze dalej i odrzucił nie tylko sam czyściec, ale także tzw. środki wstawiennicze jako nadużycie mające na celu zdobycie korzyści materialnych.

Podobnie nie podzielano prawosławnej koncepcji pośmiertnego „mytarstwa" - pokuty oraz dwustopniowego podziału podczas drugiego przyjścia Chrystusa. Uznając, iż w ten sposób nieprawi, przewrotni i gorszyciele mogą być skazani jedynie na piekło, „tedy na nic się zdały coroczne panachidy, dusz umarłych wspomnienia" ${ }^{30}$. A przecież ci, którzy z różnych powodów nie zdołali odpokutować swe niegodne czyny podczas swej ziemskiej historii, mogą przejść przez ten oczyszczający ogień i posiąść niebo. Czyściec wydaje się być jedyną możliwością łagodzącą ludzkie winy i upadki doczesne, ale także otwierającą drogę do pełnego pojednania z Bogiem. Problem dotyczył wszakże pojmowania czyśćca w kategoriach materialnych oraz kary fizycznej ${ }^{31}$, za czym opowiadała się raczej strona katolicka. Tendencji owej w żaden sposób nie tolerowała strona prawosławna, chociaż dopuszczała jakiś rodzaj cierpienia pośmiertnego w sensie duchowym i moralnym. Znaczy to, iż cała społeczność zmarłych znajduje się w jakimś ,czyśćcu”, czyli w stanie pośrednim do zmartwychwstania, lecz jeszcze niedoskonałym. W rzeczywistości skłaniano się ku akceptacji protestanckiej doktryny o usprawiedliwieniu jako zaufaniu w pełni autonomiczne działanie Boga bez współpracy człowieka. Poza tym kładąc akcent na ostatecznym spełnieniu paruzyjnym każdego, prawosławni dokonali uprzedniej redukcji katolickiego pojęcia zapłaty niebiańskiej wobec dusz sprawiedliwych ${ }^{32}$. Jednak zaistniałe tu

\footnotetext{
${ }^{29} \mathrm{H}$. PocIEJ, List dogmatyczny do patriarchy aleksandryjskiego Melecjusza, 103.

${ }^{30}$ Tamże, s. 101.

${ }^{31}$ Por. K. SAkowicz, Traktat o duszy, Kraków 1625, 140-148.

32 Por. H. Pocies, List dogmatyczny do patriarchy aleksandryjskiego Melecjusza, 184.
} 
różnice w interpretacji rzeczy przyszłych zostaną później poddane szczególnie przez prawosławnych pewnej rewizji.

\section{Zmiana percepcji}

Wskutek zaostrzonej polemiki prawosławno-katolickiej na gruncie Kościoła kijowskiego w I połowie XVII w. doprowadzono ostatecznie w samym prawosławiu do głębszej rewizji naleciałości protestanckich. Istotny wkład w tym procesie pozostaje po stronie katolików tradycji kijowskiej, którzy w trakcie wymiany kontrargumentów zaczęli coraz bardziej zdecydowanie wykazywać protestancki wpływ na prawosławne poglądy teologiczne. To wymusiło odpowiednią reakcję i znaczącą korektę prezentowanych wcześniej prawosławnych tez dogmatycznych. Najgłębszej krytyce jednak poddano ich naukę eklezjologiczną, której sprotestantyzowanie uznawali wschodni katolicy jako zerwanie z własną spuścizną duchową.

Krytyka prawosławnej eklezjologii i większości wywodów teologicznych przyniosła swój efekt w postaci stopniowego usuwania obcych naleciałości i tym samym wybijania argumentów strony przeciwnej. Prawosławni ostatecznie doszli do przekonania, że oparcie na teologii protestanckiej nie wróży im niczego dobrego na przyszłość. Tyle, że własne zaplecze w sensie gotowego kompendium wiedzy teologicznej pozostawało wciąż bardzo ubogie. Podejmowano pewne próby stworzenia podstaw prawowiernej nauki w związku z unią, ale były one niewystarczające i niedoskonałe. Podobnie zresztą sytuacja wyglądała początkowo z doktryną teologiczną katolików tradycji kijowskiej, lecz ci od samego początku byli mocno wspierani przez stronę łacińską. Ponadto pośród zwolenników unii Kościoła kijowskiego w XVII w. znajdowało się wiele osób o europejskim wykształceniu, którzy radzili sobie doskonale w kształtowaniu własnej myśli teologicznej. Choć ogólnie pozostawała ona pod wpływem łacińskim, to nosiła także znamiona odmiennego profilu wschodniego ${ }^{33}$.

Prawosławni idąc niejako w ślady swoich adwersarzy, starali się na bazie polemicznej bronić swych zasad dogmatycznych. Z tym większym natężeniem czyniono to, gdy zarzuty o protestantyzację własnej nauki zaczęły pochodzić nie tylko z zewnątrz, ale także z rodzimego środowiska. W związku z tym już na przełomie XVI i XVII w. pojawiły się dwa katechizmy braci Stefana i Wawrzyńca Tustanowskich [Kąkol] mające na celu uprawomocnić oficjalne nauczanie Kościoła, lecz nie spełniły one pożądanej roli ${ }^{34}$. Kolejny, anonimowy, kate-

${ }^{33}$ Por. E. Ozonowski, Eklezjologia unicka $w$ Polsce w latach 1596-1720, WKAB 5 (1979) nr 1, 103.

${ }^{34}$ К. Студинський (red.), Пам'ятки полемічного письменства кіния XVI і початку XVII вв., Львів 1906, 13-30. 
chizm prawosławny powstał na początku XVII w. i był skierowany przeciwko protestantom i „odszczepieńcom prawdziwej wiary” ${ }^{35}$. Następnie metodycznego opracowania podstawowych prawd wiary prawosławnej podjął się Melecjusz Smotrycki, lecz z powodu jego konwersji na katolicyzm w 1627 r. cały ten zamysł wraz z gotowym dziełem został odrzucony. Na opracowanie katechizmowe pretendowała również wydana w Kutynie w 1637 r. praca metropolity Sylwestra Kossowa (1610-1657) pt. Didaskalia albo nauka (...) o siedmiu sakramentach ${ }^{36}$.

Największy wpływ na oparcie się idei protestanckiej przez Kościół prawosławny tradycji kijowskiej oraz jego powrót do źródeł wiary prawosławnej wywarł jednak metropolita Piotr Mohyła (1596-1646). On to właśnie zdecydował się w pełni uporządkować sprawy dogmatyczne, liturgiczne i dyscyplinarne swego Kościoła, wydając w Kijowie w 1645 r. Wyznanie Wiary ${ }^{37}$, zatwierdzone wcześniej przez sobór kijowski w 1640 r. Intencją Mohyły było spowodowanie należytego oddziaływania katechizmu wewnątrz całego prawosławia. Stąd przed jego wprowadzeniem w życie zechciał poddać tekst krytycznej ocenie i zatwierdzeniu przez patriarchę Konstantynopola oraz przyjęcie przez wszystkie Kościoły lokalne jemu podległe. Chodziło tu o zachowanie lojalności wobec Kościoła macierzystego. W rezultacie katechizm po wprowadzeniu szeregu korekt został w 1643 r. zatwierdzony decyzją czterech patriarchów prawosławnych: jerozolimskiego, konstantynopolskiego, aleksandryjskiego i antiocheńskiego ${ }^{38}$.

Konstrukcja i forma katechizmu Mohyły - z 1645 r. w wersji polskiej oraz z 1646 r. w wersji staroukraińskiej - w dużym stopniu przypominały katechizmy katolickie. Pierwsza część zawiera podstawowe prawdy wiary, które zostały wyłożone wedle Symbolu Wiary. Druga część jest poświęcona znaczeniu modlitwy w życiu wierzących. Trzecia część odnosi się ściśle do dziesięciu przykazań i je szczegółowo omawia ${ }^{39}$. W całości katechizmu dostrzec można wyraźne stanowisko antyprotestanckie, które ma stanowić zarazem poważną przestrogę natury wyznaniowej. „Heretyckich ksiąg nie czytać, do zborów ich nie chodzić, kazań

35 О. ГорБАч, Три украӥнські православні катихизми 17-го віку, „Праці Богословського Факультету Українського Католицького Університету ім. Св. Климента Папи”, t. LXXI, Рим $1990,5$.

36 Oryginalne brzmienie: Дідаскаліа, альбо наука. Котораяся первій изь усть Священником Подавала О седми Сакраментах, альбили Тайнахь... . Było ono wydawane później jeszcze kilka razy, m.in. w Łucku (1638), Lwowie (1642), Kutynie (1653) i Czernihowie (1716). Por. M. Melnyk, Problematyka antropologiczna w pismach Piotra Mohyty, Olsztyn 2005, 64-65.

37 Pierwotną wersję katechizmu napisaną w języku cerkiewnosłowiańskim Mohyła sporządził wraz z Izajaszem Kozłowskim - pierwszym rektorem Kolegium Prawosławnego założonego przez Mohyłę w 1632 r.

38 Por. А. Жуковський, Встуn, w: Катехизис Петра Могили, переклад Василь Шевчук, Київ - Париж 1996, 12-14.

39 Tamże, 20-28. 
nie słuchać, także nie będąc uczestnikiem w dyskusjach z nimi nie wdawać się, i owszem strzec się ich według powiedzianego: Człowieka heretyka po jednym i drugim strofowaniu strzeżcie się"40.

Przeciwstawienie metropolity Piotra Mohyły tendencjom protestanckim w Kościele prawosławnym tradycji kijowskiej odniosło jeszcze jeden ważny skutek. Doszło bowiem do podniesienia poziomu oświaty religijnej wśród kleru, a wraz z nim w ówczesnym społeczeństwie ruskim. Stało się to dzięki powołaniu do istnienia w 1632 r. Kolegium Kijowskiego, które w 1568 r. zostaje przeksztalcone w słynną Akademię Mohylańską. Zasadniczym celem działalności danego ośrodka oświatowo-kulturowego było doprowadzenie do równoprawnego partnerstwa w relacji z katolicyzmem łacińskim i kulturą zachodnią, ponadto stworzenie należytej płaszczyzny do zjednoczenia z bratnim katolickim Kościołem kijowskim oraz ustanowienia jednego i niezależnego od Moskwy patriarchatu dla wszystkich chrześcijan miejscowej tradycji ${ }^{41}$. I choć ostatecznie nie udało się w pełni zrealizować tak ambitny projekt, to zainicjowany przez Mohyłę ruch ku odrodzeniu prawosławia i jego obrona wobec wpływu protestanckiego spełniły swoją funkcję dziejową.

\section{Bibliografia}

Dominis M.A. DE, De republica eccelesiastica, Heidelberg 1618.

Dominis M.A. DE, Papatus Romanus seu de origine progressu atque extinctione eius, w: Dictionnaire de Théologie Catholique, t. IV, London 1617, kol. 1668-1675.

Evdokimov P., Prawostawie thum. J. Klinger, Warszawa 1986.

Glemma T., Stosunki kościelne w Toruniu w stuleciu XVI i XVII na tle dziejów kościelnych Prus Królewskich, Toruń1934.

Горьач О., Три украӥнські православні катихизми 17-го віку, „Праці Богословського Факультету Українського Католицького Університету ім. Св. Климента Папи", t. LXXI, Рим 1990.

Грушевський М., Історія Украӥни-Руси, t. VIII, cz. 2, Київ 1995.

Iszczak A., De Zacharia Kopystynskyj eiusque „Palonodia” opera polemico contra prima tum R. Pontificis et unionem confecto, „Bohoslovia” 9 (1931) $1-2$, s. 64-66.

Jugie M. (red.), Theologia dogmatica christianorum orientalium, t. I, Paris 1926.

40 С. Голуьев, Киевський митрополит, t. ІІ: Приложение: „,Собрание короткой науки ... ”, Києв 1898, 405-406. 2007.

${ }^{41}$ Por. J. MoskaŁYK, Rutskiego i Mohyly projekty zjednoczenia Kościoła kijowskiego, Poznań 
Kreuza L., Obrona jedności cerkiewney abo dowody ktoremi się pokazuje, iż Grecka Cerkiew z Lacińska ma być zjednoczona, „Русская Историческа Библиотека, издаваема Археографіческой комиссиею”, t. IV, Санкт-Петербург 1878.

Melanchton F., Diepotestate papae, w: C.G. Bretschneider (wyd.), Corpus Reformatorum, t. III, Halis Saxonum 1836, kol. 271-284.

Meyendorffu., Teologia bizantyjska. Historia i doktryna, thum. J. Prokopiuk, Warszawa 1984.

МогилА П., ЕҮХОЛОГІGОN албо Молитословъ, или Требникъ, cz. 2, Київ 1647.

MoskaŁyK J., Rutskiego i Mohyly projekty zjednoczenia Kościoła kijowskiego, Poznań 2007.

Ozorowski E., Eklezjologia unicka w Polsce w latach 1596-1720, „Wiadomości Kościelne Archidiecezji Białostockiej" 5 (1979) nr 1, s. 47-104.

Pocies H., Harmonia albo konkordancja Cerkwi orientalnej z Kościołem rzymskim..., Русская Историческа Библиотека, издаваема Археографіческой комиссиею, t. VII, Санкт-Петербург 1878.

Pociej H., Kazania y homilie Męża Bożego - nieśmiertelnej sławy, y pamięci H. Pocieja. Od niedzieli przedzapustnej do niedzieli i poniedziałku Zestania Ducha Świętego, tłum. L. Kiszka, Supraśl 1714.

Pocies H., List dogmatyczny do patriarchy aleksandryjskiego Melecjusza, w: TENżE, Kazania y homilie, Supraśl 1714.

Rechowicz M., Teologia pozytywno-kontrowersyjna, w: TENże (red.), Dzieje teologii katolickiej w Polsce, t. II, cz. 1, Lublin 1975.

Runciman S., Wielki Kościól w niewoli, tłum. J.S. Łoś, Warszawa 1973.

SAKowicz K., Traktat o duszy, Kraków 1625.

SKWARCZYŃSKI P., Szkice z dziejów reformacji w Europie Środkowo-Wschodniej, Londyn 1967.

Smotrycki M., Apologia peregrynacji do krajów wschodnich..., Lwów 1628, przedr. Collected Works of Meletij Smotryc'kyj, t. I, Cambridge, MA 1987.

SмотRускі M., Consideratiae abo uważania sześciu różnic między Cerkwia Wschodnia i Zachodniq..., Lwów 1628, przedr. Collected Works of Meletij Smotryc'kyj, t. I, Cambridge, MA 1987.

Susza J., Joanni Vyhovskyj duci Cosacorum. Fuse exponit doctrinam de vera Ecclesia, de primatu Pontificis Romani, de causis schismatis Graecorum et de promovenda unione cum Ecclesia Catholica omnium Ruthenorum, w: Monumenta Ucrainae Historica, t. III, Romae 1966. 